\title{
Analysis of Organochlorine and Organophosphorus Pesticide Residues in Dairy Products and Baby Foods from Egyptian Markets
}

\section{Al-Zahraa MD ${ }^{1 *}$, Soumia MD $^{2}$ and Fathy EE}

${ }^{1}$ Department of Dairy Science, Faculty of Agriculture, Assiut University, Egypt

${ }^{2}$ Department of Food Science and Technology, Faculty of Agriculture, Assiut University, Egypt

\begin{abstract}
The residue levels of organochlorine (OCP) and organophosphorus (OPP) in some dairy products and baby foods samples in Assiut markets Egypt were determined. The concentrations of OCP and OPP were determined in milk powder, plain yoghurt, fruit yoghurt, breakfast cereals, wheat cereal-based baby foods, rice cereal-based baby foods and vegetables and fruit-based baby foods by gas chromatography/mass spectrometry. In dairy products, the highest values of OCP and OPP were $9.346 \pm 0.950 \mu \mathrm{g} / \mathrm{kg}$ methoxychlor in fruit yoghurt and $2.282 \pm 0.400 \mu \mathrm{g} / \mathrm{kg}$ disulfoton in plain yoghurt, respectively. Propachlor, dieldrin (OCP), chlorpyrifos, and parathion- methyl (OPP) were not detected in any dairy product samples. Maximum amounts of methoxychlor $(12.710 \pm 0.700 \mu \mathrm{g} / \mathrm{kg})$ and disulfoton $(5.369 \pm 0.510$ $\mu \mathrm{g} / \mathrm{kg}$ ) were recorded in vegetables and fruit-based baby foods, and wheat cereal-based baby foods, respectively. The analysis of dairy products and baby foods showed lower pesticides values than the permissible limit set by the European Commission in all products, except methoxychlor (OCP) in vegetables and fruit-based baby foods. The results will help in a scientific assessment of the implications of pesticide residues with regards to human risks in Egypt.
\end{abstract}

Keywords: Pesticide residues; Dairy products; Baby foods; Gas chromatography/mass spectrometry

\section{Introduction}

Pesticides protect crops from pests and are economically beneficial. However, these substances can transfer to the food and affect consumer health, especially in the food consumed by infants and children, who are a vulnerable risk group [1,2]. Dairy foods like milk and yoghurt are important nutritive foods for infant and the children because these include vitamin A, vitamin B12, riboflavin, calcium, carbohydrate, magnesium, phosphorus, protein, potassium, and zinc [3,4]. Moreover, processed foods such as cereals are particularly used as healthy food supplements for infants and young children. Infants and children are more vulnerable to the effects of pesticides as compared to adults because of high food consumption rate per kilogram of their body weight and low immunity [5-11]. The European Commission Directive 2006/125/EC of 5 December 2006 [12] set a limit for pesticides in cerealbased foods and baby foods for infants and young children. According to this regulation, pesticides in cereal-based foods and baby foods must not contain residues of individual pesticides at levels exceeding $10 \mu \mathrm{g} /$ $\mathrm{kg}$ (MRL). Dichlorodiphenyltrichloroethane (DDT) and its metabolites have adverse health effects such as neurodevelopment delay [13-17], reproductive effects [18], preterm and small-for-gestational-age babies [19-21], immune toxicity [7,22,23], and reduction in the mean duration of lactation (from 7 months to 3 months) [24]. Methoxychlor decreased the activity of thyroid-hormone sensitive, microsomal protein [25-29]. These food contaminants have dangerous effects in the early years of life. This fact has caused concern since dairy products and baby foods are an important exposure route for persistent pollutants in general. Limited data is available on the levels of OCP and OPP residues in dairy products and baby foods which constitute an important part of meal of many infants and children in Egypt. The aim of the current study was to determine the levels of OCP and OPP residues in the highly consumed types of foods by infants and young children: powder milk, plain yoghurt, fruit yoghurt, wheat cereal-based foods, rice cereal-based foods, breakfast cereals and vegetables, and fruit-based baby foods.

\section{Materials and Methods}

\section{Sample collection}

The most well-known seven foods that infants and children consumed (powder milk, plain yoghurt, fruit yoghurt, breakfast cereals, wheat cereal-based baby foods, rice cereal-based baby foods and vegetables and fruit-based baby foods), in large cities in Assiut Governorate (Assiut, Dirout, Manfalut, and Qusiya cities), were collected from June to October 2014 from the local pharmacies and markets of Assiut, Dirout, Manfalut, and Qusiya cities. Plain yoghurt, fruit yoghurt, vegetables and fruit baby food samples were identified, samples were kept frozen at $-20^{\circ} \mathrm{C}$ prior to analysis.

\section{Standards and reagents}

In this study, pesticide standard of the OCP group included propachlor, trifluralin, hexachlorobenzene, lindane, heptachlor, alachlor, heptachlor- epoxide, p,p-DDE, dieldrin, and methoxychlor. The OPP compounds were disulfoton, parathion- methyl, malathion, chlorpyrifos, and ethion. Acetonitrile, anhydrous sodium sulfate, and sodium chloride were used. Analytical reagents were purchased from Sigma Chemical Co., Germany.

\section{Preparation of sample extracts}

All samples were analyzed for OCP and OPP residues using rapid and easy multiresidue methodology, according to Ref. [30] and Ref.

*Corresponding author: Al-Zahraa M Darwish, Department of Dairy Science, Faculty of Agriculture, Assiut University, Egypt, Tel: +201068925078; Fax: +20882331384; E-mail: zahraadrwish@yahoo.com

Received October 11, 2016; Accepted October 24, 2016; Published October 28 2016

Citation: Al-Zahraa MD, Soumia MD, Fathy EE (2016) Analysis of Organochlorine and Organophosphorus Pesticide Residues in Dairy Products and Baby Foods from Egyptian Markets. J Environ Anal Toxicol 6: 412. doi: 10.4172/2161-0525.1000412

Copyright: ( 2016 Al-Zahraa MD, et al. This is an open-access article distributed under the terms of the Creative Commons Attribution License, which permits unrestricted use, distribution, and reproduction in any medium, provided the original author and source are credited. 
Citation: Al-Zahraa MD, Soumia MD, Fathy EE (2016) Analysis of Organochlorine and Organophosphorus Pesticide Residues in Dairy Products and Baby Foods from Egyptian Markets. J Environ Anal Toxicol 6: 412. doi: 10.4172/2161-0525.1000412

Page 2 of 5

[31]. Pesticides (5.0 g samples) were extracted from plain yoghurt, fruit yoghurt, and milk powder in a $50 \mathrm{~mL}$ disposal tube. Ethyl acetate $(20 \mathrm{~mL})$ and $3 \mathrm{~g}$ of $\mathrm{MgSO}_{4}$ were added, followed by high-speed homogenization (1 $\mathrm{min}$ ) and centrifugation (40000 rpm-10 min). Pesticides were extracted from breakfast cereals, wheat cereal-based baby foods, rice cereal-based baby foods vegetables and fruit-based baby foods using following steps. Five grams of sample was homogenized in a $50 \mathrm{~mL}$ disposal tube. Five milliliters of water was added and allowed to stand for $30 \mathrm{~min}$. Acetonitrile $(20 \mathrm{~mL})$ was added and homogenized with a high-speed homogenizer $(1 \mathrm{~min})$. Four grams of $\mathrm{MgSO}_{4}$ and $1 \mathrm{~g}$ of $\mathrm{NaCl}$ were added, and the mixture was shaken for $1 \mathrm{~min}$ [31].

\section{Gas Chromatography (GC) analysis}

Plain yoghurt, fruit yoghurt, powder milk, breakfast cereals, wheat cereal-based baby foods, rice cereal-based baby foods and vegetables and fruit-based baby foods samples were analyzed using gas chromatography/mass spectrometry (GC/MS). System 7890A series gas chromatograph coupled with model 5975B quadrupole mass spectrometer with a cross-linked 5\% phenyl methyl siloxane capillary column (DB-5MS, $30 \mathrm{~m} \times 0.25 \mathrm{~mm}$ id $\times 0.25 \mu \mathrm{m}$ film thickness) was used. The GC operating conditions were as follows: initial temperature, $90^{\circ} \mathrm{C}(7 \mathrm{~min}$ hold $)$, increased at $30^{\circ} \mathrm{C} / \mathrm{min}$ to $180^{\circ} \mathrm{C}$, increased at $4^{\circ} \mathrm{C} /$ min to $270^{\circ} \mathrm{C}$, and then increased at $30^{\circ} \mathrm{C} / \mathrm{min}$ to $280^{\circ} \mathrm{C}$ (4 min hold). Helium at a purity of $>99.999 \%$ was used as carrier gas at a flow rate of 1 $\mathrm{mL} / \mathrm{min}$. The injector port temperature was $260^{\circ} \mathrm{C}$. The sample volume injected was $2 \mu \mathrm{L}$. The MS operating conditions were as follows: solvent delay $6 \mathrm{~min}$, electron-impact (EI) mode ionization voltage $70 \mathrm{eV}$ using selected ion monitoring (SIM), and dwell time of $100 \mathrm{~ms}$ for each ion. To improve sensitivity, the selected ions used in the SIM mode are divided into fourteen groups, guided by the individual pesticide retention times. All pesticides were identified by retention time and specific ions, and quantified by the external standard method.

\section{Method validation}

We determined the quality of the method, performed a recovery fortification of the pesticide mixtures of the dairy (plain yoghurt, fruit yoghurt, and powder milk) and other (breakfast cereals, wheat cereal-based baby foods, rice cereal-based baby foods and vegetables fruit-based baby foods) samples at final concentrations of $0.02 \mu \mathrm{g} / \mathrm{kg}$ and $0.10 \mu \mathrm{g} / \mathrm{kg}$, respectively. We conducted 3 trials for each test and defined an acceptable result as the one with a recovery of $70 \sim 120 \%$ with an RSD $\leq 20 \%$ for both concentrations [31]. All samples were treated and analyzed using the GC/MS-SIM procedure described above. Pesticide residues were analysed in the analytical chemistry unit of the Laboratory at Assiut University, Egypt. Table 1 shows some parameters for determination of pesticide residues in the samples, using Agilent 7890 GC-MS.

\section{Statistical analyses}

Means and standard deviations (SD) of data were calculated with SPSS 9.0 for Windows (SPSS, Chicago, USA). Statistical software SPSS was used to perform one-way analysis of variance (ANOVA), and the least significant difference (LSD) test at a 95\% confidence level $(\mathrm{p}<0.05)$.

\section{Results and Discussion}

\section{Organochlorine pesticide residues in powder milk, plain, and fruit yoghurt}

Pesticide residues in dairy products have major effects on public health. Dairy products play a central role in nutrition of infants, children, and adults globally [32]. The concentration of persistent organochlorine compound residues in milk powder and yoghurt samples are presented in Table 2. Trifluralin, hexachlorobenzene (HCB), and lindane were detected in the analyzed milk powder samples. Concentrations range of trifluralin, HCB, and lindane varied from $0.254-0.354 \mu \mathrm{g} / \mathrm{kg}$, $0.378-0.496 \mu \mathrm{g} / \mathrm{kg}$, and $0.078-0.198 \mu \mathrm{g} / \mathrm{kg}$, respectively. The average concentration of HCB $(0.440 \pm 0.0340 \mu \mathrm{g} / \mathrm{kg})$ was higher than those of trifluralin $(0.314 \pm 0.030 \mu \mathrm{g} / \mathrm{kg})$ and lindane $(0.123 \pm 0.030 \mu \mathrm{g} / \mathrm{kg})$ in milk powder. Only p,p-DDE detected in plain yoghurt concentrations range was $0.259-0.309 \mu \mathrm{g} / \mathrm{kg}$. These results are in agreement with those recorded by Ref. [33]. Trifluralin, lindane, heptachlor, alachlor, heptachlor-epoxide, and methoxychlor were detected in fruit yoghurt (Table 2). Average concentration of trifluralin and Lindane were 0.157 $\pm 0.017 \mu \mathrm{g} / \mathrm{kg}$ and $2.505 \pm 0.043 \mu \mathrm{g} / \mathrm{kg}$ in fruit yoghurt, respectively. Lindane concentrations range were higher than those reported in plain yoghurt in Ghana $(0.03 \mu \mathrm{g} / \mathrm{kg})$ [33]. Propachlor and dieldrin were not detected in dairy food samples. Alachlor, heptachlor- epoxide, and methoxychlor were detected only in fruit yoghurt with average values of $0.242 \pm 0.043 \mu \mathrm{g} / \mathrm{kg}, 1.616 \pm 0.64 \mu \mathrm{g} / \mathrm{kg}$, and $9.346 \pm 0.950 \mu \mathrm{g} / \mathrm{kg}$, respectively. In the present study, the values of OCP in milk powder, and plain and fruit yoghurt did not exceed the permissible limit set by the European Commission, 2006 [12]. The decrease in the residue levels of these pesticides may be due to the heat-treated milk and dairy products [34]. Organochlorine pesticides can contaminate milk-producing animals through grass feeding and inhaled air and accumulate in fatrich dairy products [35].

\section{Organophorous pesticide residues in milk powder, plain yoghurt, and fruit yoghurt}

The residues of OPP pesticides in milk powder, plain yoghurt, and fruit yoghurt samples are shown in Table 3. The OPP detection includes disulfoton, malathion, and ethion, while the parathion-methyl and chlorpyrifos are not detected in all dairy products samples. Only disulfoton $(0.263-0.523 \mu \mathrm{g} / \mathrm{kg})$ was detected in the analyzed milk powder samples. Disulfoton and malathion were detected in plain yoghurt at concentrations range of $1.576-2.966 \mu \mathrm{g} / \mathrm{kg}$ and $0.279-0.489 \mu \mathrm{g} / \mathrm{kg}$, respectively. OPP pesticides in fruit yoghurt were in the malathion and ethion $1.308-3.974 \mu \mathrm{g} / \mathrm{kg}$ and $0.644-0.801 \mu \mathrm{g} / \mathrm{kg}$ concentration range, respectively. Malathion was detected only in yoghurt samples, with concentration range of $0.279-0.489 \mu \mathrm{g} / \mathrm{kg}$ and $1.308-3.974 \mu \mathrm{g} / \mathrm{kg}$ in plain yogurt and fruit yogurt samples, respectively. Ethion was detected only in fruit yoghurt samples at a concentration range of 0.644-0.801 $\mu \mathrm{g} / \mathrm{kg}$. These results were in agreement with Ref. [36], who reported that malathion was enhanced during yoghurt processing or heat treatment [37]. Analyzed OPP contamination in 135 raw milk samples residues ranging from $5 \mu \mathrm{g} / \mathrm{kg}$ to $18 \mu \mathrm{g} / \mathrm{kg}$. These concentrations were higher than those recorded from treated dairy products (milk powder and yoghurt), because of a decrease in OPP in milk during heat treatment or yoghurt processing. In the present study, disulfoton, malathion, and ethion levels did not exceed the permissible limit $(10 \mu \mathrm{g} / \mathrm{kg})$ proposed by European Commission (2006) [12] (Table 3).

\section{Organochlorine pesticide residues in breakfast cereals, wheat cereal-based baby foods, rice cereal-based baby foods and vegetable, and fruit-based baby foods}

The OCP pesticides in breakfast cereals samples were lindane 0.452 $\pm 0.052 \mu \mathrm{g} / \mathrm{kg}$ and dieldrin $1.892 \pm 0.810 \mu \mathrm{g} / \mathrm{kg}$. Propachlor, lindane, and heptachlor were detected at concentrations of $0.43 \pm 0.042 \mu \mathrm{g} / \mathrm{kg}, 1.068$ $\pm 0.340 \mu \mathrm{g} / \mathrm{kg}$, and $2.061 \pm 0.69 \mu \mathrm{g} / \mathrm{kg}$, respectively, in wheat cerealbased baby foods. Lindane is used against a wide range of insects as an 
Citation: Al-Zahraa MD, Soumia MD, Fathy EE (2016) Analysis of Organochlorine and Organophosphorus Pesticide Residues in Dairy Products and Baby Foods from Egyptian Markets. J Environ Anal Toxicol 6: 412. doi: 10.4172/2161-0525.1000412

Page 3 of 5

\begin{tabular}{|c|c|c|c|}
\hline Pesticides & $\begin{array}{c}\text { Retention time } \\
(\mathbf{m i n})\end{array}$ & $\begin{array}{c}\text { LOD }^{*} \\
\left(\boldsymbol{\mu g L ^ { - 1 }}\right)\end{array}$ & $\begin{array}{c}\text { Target ion (qualifier ion) } \\
(\mathbf{m} / \mathbf{z})\end{array}$ \\
\hline Propachlor & 9.97 & 0.0030 & 181.00 \\
\hline Tirfluralin & 10.42 & 0.0010 & 306.00 \\
\hline Hexachlorobenzene & 11.17 & 0.0020 & 284.00 \\
\hline Lindane & 11.86 & 0.0001 & 183.00 \\
\hline Disulfoton & 12.41 & 0.0007 & 89.00 \\
\hline Parathion- Methyl & 13.60 & 0.0001 & 125.00 \\
\hline Heptachlor & 13.93 & 0.0050 & 100.00 \\
\hline Alachlor & 13.61 & 0.0060 & 160.00 \\
\hline Malathion & 14.68 & 0.0010 & 173.10 \\
\hline Chlorpyrifos & 14.89 & 0.0002 & 196.90 \\
\hline Heptachlor-epoxide & 16.39 & 0.0010 & 353.00 \\
\hline p,p-DDE & 18.72 & 0.0001 & 105.00 \\
\hline Dieldrin & 18.74 & 0.0002 & 262.90 \\
\hline Ethion & 20.25 & 0.0003 & 231.00 \\
\hline Methoxychlor & 24.09 & 0.0191 & 228.00 \\
\hline
\end{tabular}

Table 1: Parameters for determination of pesticide residues in milk powder, plain and fruit yoghurt, breakfast cereals, wheat and rice cereal-based baby foods and vegetables and fruit baby foods by GC/MS.

\begin{tabular}{|c|c|c|c|c|c|c|}
\hline \multirow[b]{3}{*}{ Pesticides } & \multicolumn{6}{|c|}{ Type of dairy products } \\
\hline & \multicolumn{2}{|c|}{ Milk powder } & \multicolumn{2}{|c|}{ Plain yogurt } & \multicolumn{2}{|c|}{ Fruit yoghurt } \\
\hline & $\begin{array}{c}\text { Concentration range } \\
(\mu \mathrm{g} / \mathrm{kg})\end{array}$ & $\begin{array}{c}\text { Average }^{*} \\
\text { concentration } \\
(\mu \mathrm{g} / \mathrm{kg})\end{array}$ & $\begin{array}{c}\text { Concentration range } \\
(\mu \mathrm{g} / \mathrm{kg})\end{array}$ & $\begin{array}{c}\text { Average } \\
\text { concentration } \\
(\mu \mathrm{g} / \mathrm{kg})\end{array}$ & $\begin{array}{c}\text { Concentration range } \\
(\mu \mathrm{g} / \mathrm{kg})\end{array}$ & $\begin{array}{c}\text { Average } \\
\text { concentration } \\
(\mu \mathrm{g} / \mathrm{kg})\end{array}$ \\
\hline Propachlor & ND & ND & ND & ND & ND & ND \\
\hline Tirfluralin & $0.254-0.354$ & $0.314 \pm 0.030$ & ND & ND & $0.133-0.191$ & $0.157 \pm 0.017$ \\
\hline Hexachlorobenzene & $0.378-0.496$ & $0.440 \pm 0.034$ & ND & ND & ND & ND \\
\hline Lindane & $0.078-0.198$ & $0.123 \pm 0.030$ & ND & ND & $2.440-2.548$ & $2.505 \pm 0.043$ \\
\hline Heptachlor & ND & ND & ND & ND & $1.463-1.783$ & $1.616 \pm 0.051$ \\
\hline Alachlor & ND & ND & ND & ND & $0.146-0.355$ & $0.242 \pm 0.043$ \\
\hline Heptachlor- epoxide & ND & ND & ND & ND & $1.5-1.722$ & $1.616 \pm 0.064$ \\
\hline$p, p-D D E$ & ND & ND & $0.259-0.309$ & $0.259 \pm 0.050$ & ND & ND \\
\hline Dieldrin & ND & ND & ND & ND & ND & ND \\
\hline Methoxychlor & ND & ND & ND & ND & $9.158-9.467$ & $9.346 \pm 0.095$ \\
\hline
\end{tabular}

Table 2: Organochlorine pesticides $(\mu \mathrm{g} / \mathrm{kg}))$ detected in milk powder and plain and fruit yoghurts.

\begin{tabular}{|c|c|c|c|c|c|c|}
\hline \multirow{3}{*}{ Pesticides } & \multicolumn{6}{|c|}{ Type of dairy products } \\
\hline & \multicolumn{2}{|c|}{ Milk powder } & \multicolumn{2}{|c|}{ Plain yogurt } & \multicolumn{2}{|c|}{ Fruit yoghurt } \\
\hline & $\begin{array}{l}\text { Concentration range } \\
(\mu \mathrm{g} / \mathrm{kg})\end{array}$ & $\begin{array}{c}\text { Average }^{*} \\
\text { concentration } \\
(\mu \mathrm{g} / \mathrm{kg})\end{array}$ & $\begin{array}{l}\text { Concentration range } \\
(\mu \mathrm{g} / \mathrm{kg})\end{array}$ & $\begin{array}{c}\text { Average } \\
\text { concentration } \\
(\mu \mathrm{g} / \mathrm{kg})\end{array}$ & $\begin{array}{c}\text { Concentration range } \\
(\mu \mathrm{g} / \mathrm{kg})\end{array}$ & $\begin{array}{c}\text { Average } \\
\text { concentration } \\
(\mu \mathrm{g} / \mathrm{kg})\end{array}$ \\
\hline Disulfoton & $0.263-0.523$ & $0.403 \pm 0.070$ & $1.576-2.966$ & $2.282 \pm 0.400$ & ND & ND \\
\hline Parathion- methyl & ND & ND & ND & ND & ND & ND \\
\hline Malathion & ND & ND & $0.279-0.489$ & $0.397 \pm 0.060$ & $1.308-3.974$ & $2.296 \pm 0.790$ \\
\hline Chlorpyrifos & ND & ND & ND & ND & ND & ND \\
\hline Ethion & ND & ND & ND & ND & $0.644-0.801$ & $0.700 \pm 0.050$ \\
\hline
\end{tabular}

*Average concentration: mean \pm SD; ND: not detected

Table 3: Organophorous pesticides $(\mu \mathrm{g} / \mathrm{kg}))$ detected in milk powder and plain and fruit yoghurts.

insecticide and fumigant, and is thus found in food products, including fruits, vegetables and milk products. HCB $0.586 \pm 0.043 \mu \mathrm{g} / \mathrm{kg}$ was only detected in rice cereal-based baby foods. Lindane, heptachlor, and methoxychlor were found in vegetables and fruit-based baby foods with average values of $2.464 \pm 0.600 \mu \mathrm{g} / \mathrm{kg}, 1.717 \pm 0.780 \mu \mathrm{g} / \mathrm{kg}$, and 12.710 $\pm 0.700 \mu \mathrm{g} / \mathrm{kg}$, respectively (Table 4). The European Commission 2003 [38] has reported maximum residue levels (MRLs) for pesticides in processed cereal-based baby foods at $10 \mu \mathrm{g} / \mathrm{kg}$. In the current study, all analyzed baby foods samples showed lower pesticide residues than the permissible limit set by the European Commission [38], except methoxychlor in vegetables and fruit-based baby foods.
Organophorous pesticide residues in breakfast cereals, wheat cereal-based baby foods, rice cereal-based baby foods and vegetables and fruit-based baby foods

OPP residues were detected in baby foods, including disulfoton, malathion, and ethion with average concentration of $3.758 \pm 0.780$ $\mu \mathrm{g} / \mathrm{kg}, 0.353 \pm 0.086 \mu \mathrm{g} / \mathrm{kg}$, and $2.274 \pm 0.880 \mu \mathrm{g} / \mathrm{kg}$, respectively, in breakfast cereals. These values were lower than the permissible limit set by the European Commission [38]. Disulfoton at mean values of 5.369 $\pm 0.510 \mu \mathrm{g} / \mathrm{kg}$ was detected in wheat cereal-based baby food. Parathionmethyl, chlorpyrifos, and ethion with mean values of $3.191 \pm 0.52 \mu \mathrm{g} /$ 
Citation: Al-Zahraa MD, Soumia MD, Fathy EE (2016) Analysis of Organochlorine and Organophosphorus Pesticide Residues in Dairy Products and Baby Foods from Egyptian Markets. J Environ Anal Toxicol 6: 412. doi: 10.4172/2161-0525.1000412

Page 4 of 5

\begin{tabular}{|c|c|c|c|c|c|c|c|c|}
\hline \multirow{3}{*}{ Pesticides } & \multicolumn{8}{|c|}{ Type of baby foods } \\
\hline & \multicolumn{2}{|c|}{ Breakfast cereals } & \multicolumn{2}{|c|}{ Wheat cereal-based baby foods } & \multicolumn{2}{|c|}{ Rice cereal-based baby foods } & \multicolumn{2}{|c|}{ Vegetables and fruit baby foods } \\
\hline & $\begin{array}{c}\text { Concentration } \\
\text { range } \\
(\mu \mathrm{g} / \mathrm{kg})\end{array}$ & $\begin{array}{c}\text { Average }^{*} \\
\text { concentration } \\
(\mu \mathrm{g} / \mathrm{kg})\end{array}$ & $\begin{array}{c}\text { Concentration } \\
\text { range } \\
(\mu \mathrm{g} / \mathrm{kg})\end{array}$ & $\begin{array}{c}\text { Average } \\
\text { concentration } \\
(\mu \mathrm{g} / \mathrm{kg})\end{array}$ & $\begin{array}{c}\text { Concentration } \\
\text { range } \\
(\mu \mathrm{g} / \mathrm{kg})\end{array}$ & $\begin{array}{c}\text { Average } \\
\text { concentration } \\
(\mu \mathrm{g} / \mathrm{kg})\end{array}$ & $\begin{array}{c}\text { Concentration } \\
\text { range } \\
(\mu \mathrm{g} / \mathrm{kg})\end{array}$ & $\begin{array}{c}\text { Average } \\
\text { concentration } \\
(\mu \mathrm{g} / \mathrm{kg})\end{array}$ \\
\hline Propachlor & ND & ND & $0.346-0.472$ & $0.43 \pm 0.042$ & ND & ND & ND & ND \\
\hline Tirfluralin & ND & ND & ND & ND & ND & ND & ND & ND \\
\hline Hexachlorobenzene & ND & ND & ND & ND & $0.491-0.663$ & $0.586 \pm 0.043$ & ND & ND \\
\hline Lindane & $0.398-0.558$ & $0.452 \pm 0.052$ & $0.561-1.719$ & $1.068 \pm 0.340$ & ND & ND & $1.864-3.064$ & $2.464 \pm 0.600$ \\
\hline Heptachlor & ND & ND & $0.681-2.981$ & $2.061 \pm 0.69$ & ND & ND & $0.724-3.277$ & $1.717 \pm 0.780$ \\
\hline Alachlor & ND & ND & ND & ND & ND & ND & ND & ND \\
\hline Heptachlor- epoxide & ND & ND & ND & ND & ND & ND & ND & ND \\
\hline$p, p-D D E$ & ND & ND & ND & ND & ND & ND & ND & ND \\
\hline Dieldrin & $0.272-3.512$ & $1.892 \pm 0.810$ & ND & ND & ND & ND & ND & ND \\
\hline Methoxychlor & ND & ND & ND & ND & ND & ND & $11.17-13.97$ & $12.710 \pm 0.700$ \\
\hline
\end{tabular}

Table 4: Organochlorine pesticides $(\mu \mathrm{g} / \mathrm{kg})$ detected in breakfast cereals, wheat and rice cereal-based baby foods and vegetables and fruit baby foods.

\begin{tabular}{|c|c|c|c|c|c|c|c|c|}
\hline \multirow{3}{*}{ Pesticides } & \multicolumn{8}{|c|}{ Type of baby foods } \\
\hline & \multicolumn{2}{|c|}{ Breakfast cereals } & \multicolumn{2}{|c|}{ Wheat cereal-based baby foods } & \multicolumn{2}{|c|}{ Rice cereal-based baby foods } & \multicolumn{2}{|c|}{ Vegetables and fruit baby foods } \\
\hline & $\begin{array}{c}\text { Concentration } \\
\text { range } \\
(\mu \mathrm{g} / \mathrm{kg})\end{array}$ & $\begin{array}{c}\text { Average }^{*} \\
\text { concentration } \\
(\mu \mathrm{g} / \mathrm{kg})\end{array}$ & $\begin{array}{c}\text { Concentration } \\
\text { range } \\
(\mu \mathrm{g} / \mathrm{kg})\end{array}$ & $\begin{array}{c}\text { Average } \\
\text { concentration } \\
(\mu \mathrm{g} / \mathrm{kg})\end{array}$ & $\begin{array}{c}\text { Concentration } \\
\text { range } \\
(\mu \mathrm{g} / \mathrm{kg})\end{array}$ & $\begin{array}{c}\text { Average } \\
\text { concentration } \\
(\mu \mathrm{g} / \mathrm{kg})\end{array}$ & $\begin{array}{c}\text { Concentration } \\
\text { range } \\
(\mu \mathrm{g} / \mathrm{kg})\end{array}$ & $\begin{array}{c}\text { Average } \\
\text { concentration } \\
(\mu \mathrm{g} / \mathrm{kg})\end{array}$ \\
\hline Disulfoton & $2.588-5.262$ & $3.758 \pm 0.780$ & $4.349-6.389$ & $5.369 \pm 0.51$ & ND & ND & ND & ND \\
\hline $\begin{array}{l}\text { Parathion- } \\
\text { Methyl }\end{array}$ & ND & ND & ND & ND & $2.151-4.231$ & $3.191 \pm 0.52$ & ND & ND \\
\hline Malathion & $0.163-0.5078$ & $0.353 \pm 0.086$ & ND & ND & ND & ND & ND & ND \\
\hline Chlorpyrifos & ND & ND & ND & ND & $0.517-0.807$ & $0.649 \pm 0.079$ & ND & ND \\
\hline Ethion & $0.514-3.154$ & $2.274 \pm 0.880$ & ND & ND & 0.686-0.899 & $0.758 \pm 0.072$ & ND & ND \\
\hline
\end{tabular}

Table 5: Organophorous pesticides $(\mu \mathrm{g} / \mathrm{kg})$ detected in in breakfast cereals, wheat and rice cereal-based baby foods and vegetables and fruit baby foods.

$\mathrm{kg}, 0.649 \pm 0.079 \mu \mathrm{g} / \mathrm{kg}$, and $0.758 \pm 0.072 \mu \mathrm{g} / \mathrm{kg}$, respectively were found in rice cereal-based baby foods (Table 5).

\section{Conclusions}

The overall results show that OCP and OPP residues in dairy products (milk powder and plain and fruit yoghurts, baby foods (breakfast cereals, wheat and rice cereal-based baby foods and vegetables and fruit-based baby foods) in Assiut markets Egypt. The highest mean values of OCP and OPP were methoxychlor at mean concentrations of $9.346 \pm 0.950 \mu \mathrm{g} / \mathrm{kg}$ and $2.282 \pm 0.400 \mu \mathrm{g} / \mathrm{kg}$ in fruit yoghurt and plain yoghurt, respectively. Propachlor and dieldrin (OCP), chlorpyrifos, and parathion- methyl were absent in all analyzed dairy products. Methoxychlor (OCP) and disulfoton (OPP) showed the highest mean values of $12.710 \pm 0.700 \mu \mathrm{g} / \mathrm{kg}$ and $5.369 \pm 0.510 \mu \mathrm{g} / \mathrm{kg}$ in vegetables and fruit-based baby foods, and wheat cereal-based baby food, respectively. The order for the contamination in the analyzed dairy products and baby food were milk powder $>$ fruit yoghurt $>$ plain yoghurt and wheat cereal-based baby foods breakfast cereals $>$ fruit yoghurt>rice cereal-based baby foods $>$ vegetables and fruit baby foods, respectively. The results from these studies show that residues of OCP and OPP pesticides are present in dairy products, breakfast cereals, cereal-based baby food and vegetables and fruit-based baby foods. Their concentrations were lower than the acceptable maximum residue levels, except methoxychlor in vegetables and fruit-based baby foods. Although these pesticides residues occurred at very low concentrations in the samples, they may accumulate to higher levels in infant and young children upon consumption. The results of this survey demonstrate the need to establish pesticide residue monitoring programs in consumables to improve food safety and decrease health risks in consumers.

\section{Acknowledgements}

This research was financially supported by Assuit University, Egypt.

\section{References}

1. Gentili A, Perret D, Marchese S, Sergi M, Olmi CR (2004) Accelerated solvent extraction and confirmatory analysis of sulfonamide residues in raw meat and infant foods by liquid chromatography electrospray tandem mass spectrometry. J Agric Food Chem 52: 4614-4624.

2. Hercegová A, Domotorova M, Matisova E (2007) Sample preparation methods in the analysis of pesticide residues in baby food with subsequen chromatographic determination. J Chromatogr A 1153: 54-73.

3. Nutrition Australia (2009) Promoting optimal health by encouraging food variety and physical activity. Infant nutration, Australia.

4. Abou-Dounia MA, Abou-Arab AAK, El-Senaity MH, Abd-Rabou NS (2010) Chemical composition of raw milk and the Accumulation of pesticide residues in milk productis. Global veterinaria 4: 6-14

5. Repetto R, Baliga SS (1997) Pesticides and immunosuppression: the risks to public health. Health Policy Plan 12: 97-106.

6. Chapin RE, Harris MW, Davis BJ, Ward SM, Wilson RE, et al. (1997) The effects of perinatal/juvenile methoxychlor exposure on adult rat nervous, immune, and reproductive system function. J Toxicol Sci 40: 138-157.

7. Yáñez L, Ortiz-Pérez D, Batres LE, Borja-Aburto VH, Díaz-Barriga $F(2002)$ Levels of dichlorodiphenyltrichloroethane and deltamethrin in humans and environmental samples in malarious areas of Mexico. Environ Res 88: 174-181. 
Citation: Al-Zahraa MD, Soumia MD, Fathy EE (2016) Analysis of Organochlorine and Organophosphorus Pesticide Residues in Dairy Products and Baby Foods from Egyptian Markets. J Environ Anal Toxicol 6: 412. doi: 10.4172/2161-0525.1000412

8. Gladen BC, Shkiryak-Nyzhnyk ZA, Chyslovska N, Zadorozhnaja TD, Little RE (2003) Persistent organochlorine compounds and birth weight. Ann Epidemiol 13: $151-157$

9. Holsapple MP, Paustenbach DJ, Charnley G, West LJ, Luster MI, et al. (2004) Symposium summary: Children's Health Risk-What's So Special about the Developing Immune System?. Toxicol Appl Pharmacol 199: 61-70.

10. Landrigan PJ, Kimmel CA, Correa A, Eskenazi B (2004) Children's health and the environment: public health issues and challenges for risk assessment. Environ Health Perspect 112: 257-265.

11. Aguilera-Luiz M, Vidal JM, Romero-González R, Frenich AG (2012) Multiclass method for fast determination of veterinary drug residues in baby food by ultrahigh-performance liquid chromatography-tandem mass spectrometry. Food chem 4: 2171-2180.

12. European Commission (2006) Commission Directive 2006/141/EC, Infan formulae and follow-on formulae and amending Directive 1999/21/EC. Off $J$ Eur Union.

13. Ribas-Fitó N, Sala M, Cardo E, Mazón C, De Muga ME, et al. (2002) Association of hexachlorobenzene and other organochlorine compounds with anthropometric measures at birth. Pediatr Res 52:163-167.

14. Eskenazi B, Marks AR, Bradman A, Fenster L, Johnson C, et al. (2005) In utero exposure to dichlorodiphenyltrichloroethane (DDT) and dichlorodiphenyldichloroethylene (DDE) and neurodevelopment among young mexican american children. Pediatrics 118: 233-241.

15. Eskenazi B, Rosas LG, Marks AR, Bradman A, Harley K, et al. (2008) Pesticide toxicity and the developing brain. Basic Clin Pharmacol Toxicol 102: 228-236.

16. Rosas LG, Eskenazi B (2008) Pesticides and child neurodevelopment. Current Opinion in Pediatrics 20: 191-197.

17. Julvez J, Grandjean P (2009) Neuro developmental toxicity risks due to occupational exposure to industrial chemicals during pregnancy. Ind Health 47 : 459-468

18. Dalvie MA, Myers JE, Thompson ML, Robins TG, Dyer S, et al. (2004) The long-term effects of DDT exposure on semen, fertility, and sexual function of malaria vector-control workers in Limpopo Province. South Africa Environ Res 96: 1-8.

19. Lonġnecker M, Klebanoff M, Zhou H, Brock J (2001) Association between maternal serum concentration of the DDT metabolite DDE and preterm and small-for-gestational-age babies at birth. J Lancet 358: 110-114.

20. Farhang L, Weintraub JM, Petreas M, Eskenazi B, Bhatia R (2005) Association of DDT and DDE with birth weight and length of gestation in the child health and development studies, 1959-1967. Am J Epidemiol 162: 717-725.

21. Khanjani N, Sim MR (2006) Maternal contamination with dichlorodiphenyltrichloroethane and reproductive outcomes in an Australian population. Environ Res 101: 373-379.

22. Turusov V, Rakitsky V, Tomatis L (2002) Dichlorodiphenyltrichloroethane (DDT): ubiquity, persistence, and risks. Environmental health perspectives 110: 125-128.
23. Cooper GS, Martin SA, Longnecker MP, Sandler DP, Germolec DR (2004) Associations between plasma DDE levels and immunologic measures in African-American farmers in North Carolina. Environ Health Perspect 112 1080-1084.

24. Gladen BC, Rogan WJ (1995) DDE and shortened duration of lactation in a northern Mexican town. Am J Public Health 85: 504-508.

25. Zhou LX, Dehal SS, Kupfer D, Morrell S, McKenzie BA, et al. (1995) Cytochrome P450 catalyzed covalent binding of methoxychlor to rat hepatic, microsomal iodothyronine 5'-monodeiodinase, type I: does exposure to methoxychlor disrupt thyroid hormone metabolism?. Arch Biochem Biophys 322: 390-394.

26. Morrell SL (1997) Toxicological effects of methoxychlor on thyroid hormone metabolism.

27. Kitamura S, Jinno N, Ohta S, Kuroki H, Fujimoto N (2002) Thyroid hormonal activity of the flame retardants tetrabromobisphenol $A$ and tetrachlorobisphenol A. Biochemical and biophysical research communications 293: 554-559.

28. Rogan WJ, Ragan NB (2003) Evidence of effects of environmental chemicals on the endocrine system in children. Pediatrics 112: 247-252.

29. Patrick $L$ (2009) Thyroid disruption: mechanisms and clinical implications in human health. Altern Med Rev 14: 326-347.

30. Kitagawa Y, Okihashi M, Takatori S, Okamoto Y, Fukui N, et al. (2009) Multiresidue method for determination of pesticide residues in processed foods by gc/ms. Shokuhin Eiseigaku Zasshi 50: 198-207.

31. Takatori S, Okihashi M, Kitagawa Y, Fukui N, Kakimoto-Okamoto Y, (2011) Rapid and easy multiresidue method for determination of pesticide residues in foods using gas or liquid chromatography-tandem mass spectrometry. Margarita S (ed.) pesticides - strategies for pesticides analysis. InTech Open, pp: 198-214.

32. Jahed Khaniki GHR (2007) Chemical contaminants in milk and public health concerns: A review. Int J Dairy Sci 2: 104-115.

33. Darko G, Acquaah SO (2008) Levels of organochlorine pesticides residues in dairy products Kumasi, Ghana. Chemosphere 71: 294-298.

34. Castro MFPM, Oliveira JJV, Rodrigues J, Loredo ISD, Oliveira JJ, et al. (2002) Study on the persistence of trifluralin, chlorpyrifos, decamethrin, cypermethrin and dichlorvos in rice and beans after cooking in a commercial microwave oven. Advances-in-stored-productprotection. In: Credland PF, Armitage DM, Bell CH Cogan PM (eds.) Proceedings of the 8th international working conference on stored product protection, New York, UK, pp: 517-521.

35. Waliszewski SM, Pardio VT, Waliszewski KN, Chantiri JN, Agurrie AA, et al (1997) Organochlorine pesticide residues in cow's milk and butter in Mexico. Sci Total Environ 208: 127-132.

36. Bo L, Zhang Y, Zhao X (2011) Degradation kinetics of seven organophosphorus pesticides in milk during yoghurt processing. J Serb Chem Soc 76: 353-362.

37. Pagliuca G, Serraino A, Gazzotti T, Zironi E, Borsari A, et al. (2006) Organophosphorus pesticides residues in Italian raw milk. J Dairy Res 73: 340-344.

38. European Commission (2003) (EC) Amending Directive 96/5/EC on processed cereal-based food sand baby foods for infants and young children. Off $\mathrm{J}$ Eur Union 41: 33. 